EISSN:2706-7920 ISSN: 2077-4435

DOI: 10.36632/csi/2021.10.4.42

Journal homepage: www.curresweb.com

Pages: 485-504

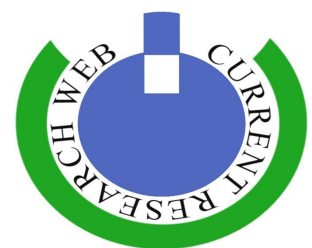

\title{
Using ASTER Remote Sensing Data Set for Geological Mapping around Wadi Umm Ashira and Wadi Tilal Al-Qulieb, Northwestern Part of Wadi Allaqi, South Eastern Desert, Egypt
}

\section{Nehal M.A. Soliman'1, Hatem M. El-Desoky ${ }^{2}$, Mohamed A. Heikal ${ }^{2}$ and Ahmed M.Abdel-Rahman ${ }^{2}$}

${ }^{1}$ National Authority for Remote Sensing and Space Sciences (NARSS), Cairo1564, Egypt.

${ }^{2}$ Geology Department, Faculty of Science, Al-Azhar University, PO Box 11884, Nasr City, Cairo, Egypt.

\author{
Received: 15 April $2021 \quad$ Accepted: 06 June $2021 \quad$ Published: 15 Oct. 2021
}

\begin{abstract}
This study is an attempt to apply ASTER (VNIR \& SWIR) data and fieldwork to identifying variations in rock units and structural elements. The study area is located in the northwestern segment of the Wadi Allaqi, South Eastern Desert, Egypt. Color Ratio Composites, band math, false color composites and principal component analysis techniques are used to refine the different lithologic units in the area. These methods showed the discrimination of different types of metamorphic and igneous rocks as well as dykes. The False color band combinations (b4, b5, b3) in RGB, Color Ratio Composites $(4 / 1,6 / 2,8 / 2)$ and $(4 / 7,3 / 4,2 / 1$ respectively) for RGB are showing a good composite which separated between the different rock types in the study area especially, serpentinites, talc carbonate and marble. The Principal Component Analysis technique of ASTER (PC3, PC1, PC4 in RGB respectively), (PC2, PC3, PC1 in RGB respectively) and (PC4, PC2, PC1 in RGB respectively) enhances the main structural trends affecting the area under investigation. These images are considered good for lithologic and structural edge enhancements for both visual interpretation and field mapping. FCC image 4, 5, 3 in RGB is showing a large open fold as well as the major left-strike slip fault and restraining (augen) shape as a result of being affected by the Allaqi Heiani shear zone. The axial plane of an anticlinal fold-oriented NW-SE and is plunging with a moderate angle to the SE. The major strike- slip fault is wadi Um Arka sinistral fault that runs subparallel to Um Ashira major fault that led to lateral movement of metasediment and the marble bands horizontal displacements of about $100 \mathrm{~m}$ to $747 \mathrm{~m}$. Restraining bend structure (sigmoidal=augen shape) formed a result of a sinistral fault. The final map according to field study and remote sensing methodology showing the lithological composition and structure localities.
\end{abstract}

Keywords: Remote sensing, ASTER image, Allaqi-Heiani suture, Microstructure, Strike slip Fault, Folding.

\section{Introduction}

\section{Allaqi-Heiani Suture}

Allaqi-Heiani zone represents the most obvious structural feature in the extreme SED of Egypt (Fig.1). This zone was described for the first time by Taylor et al., (1993) and has been mentioned in numerous studies later on (e.g., Greiling et al., 1994; EGSMA, 1996; Hamimi and El-Kazzaz 2000, Abdeen et al., 2001\&2011). It extends over $200 \mathrm{~km}$ (average width $3 \mathrm{~km}$ ) from Gabal Um Shilman and probably on Nasser Lake in the west to the NNE-trending Hamisana Shear Zone in the east. The strike of this zone is remarkably variable from E-W, NW-SE and N-S. Such strike variation makes it to be perpendicular to the main Wadi Allaqi to the west (Fig.1) and align the southern flank of the 
same wadi to the east, where it is apparently cut by the NE-oriented Hamisana Shear Zone (Greiling et al., 1994).

Wadi Tilal Al-Qulieb and Wadi Um Ashira area is situated to the northwest segment of Wadi Allaqi, South Eastern Desert of Egypt, nearby the eastern bank of Nasser Lake (Fig.1). The study area covers about $400 \mathrm{~km}^{2}$, between longitudes $33^{\circ} 15^{\prime}-33^{\circ} 30^{\prime} \mathrm{E}$ and latitudes $22^{\circ} 40^{\prime}-23^{\circ} 00^{\prime} \mathrm{N}$. The area under investigation is shown on the geologic map of Wadi Gabgaba quadrangle Egypt sheet No.NF 36 NE (scale 1:250.000), published by EGSMA (1996).

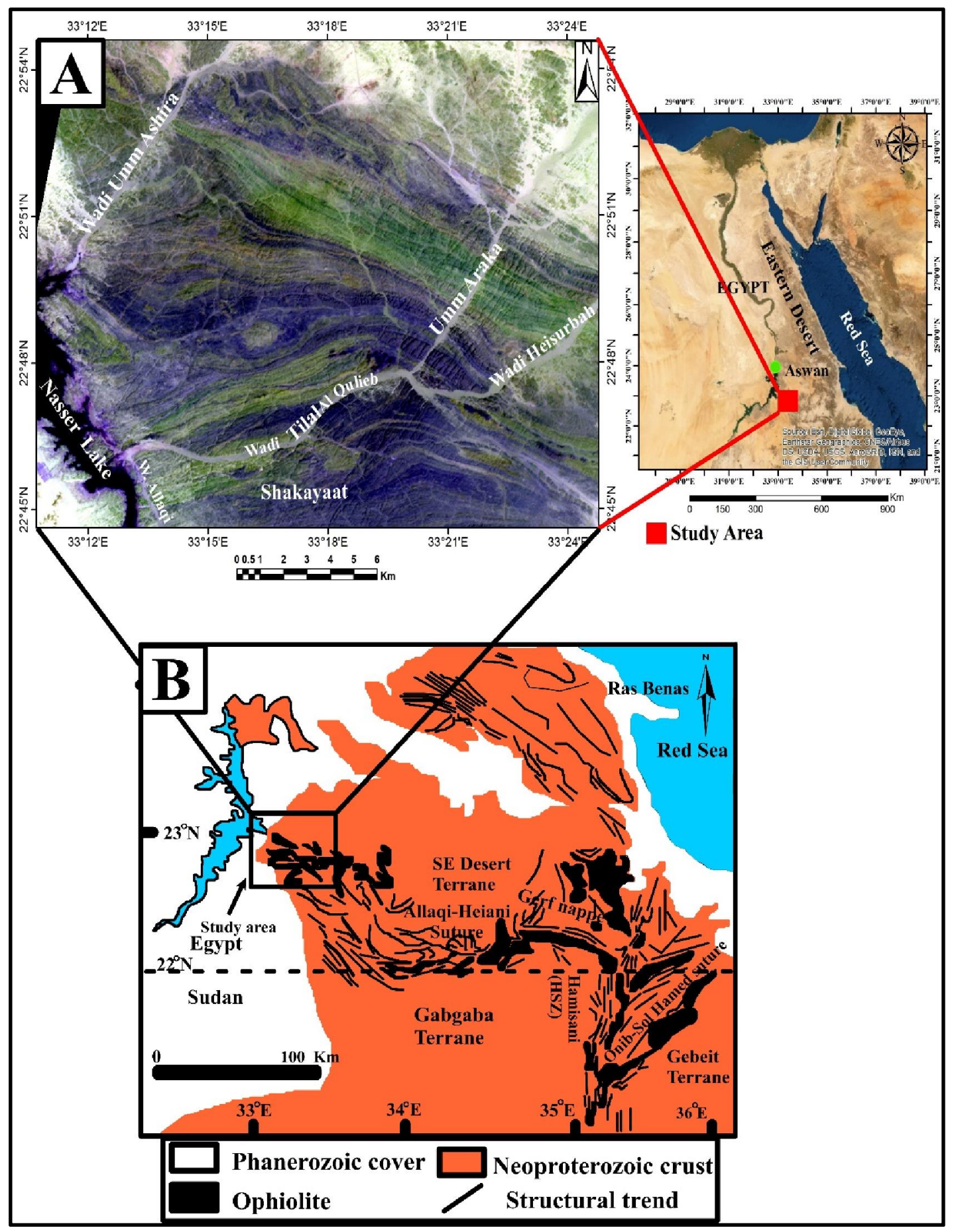

Fig.1: A- Location map of the studied area by ASTER band ratio (4/7, 3/4, 2/1) RGB (modified after Abrams et al., 1983). B- The Northern part of the Nubian Shield includes the present area with structural features, compiled from Sultan et al., (1987), Greiling et al., (1994) and Abdelsalam et al., (1996). 
The basement complex cropping out around Wadi Tilal Al-Qulieb and Wadi Umm Ashira area comprises ultramafic rocks, metasediments, metagabbro-diorite, granodiorite and dykes. The following lines are a detailed description of remote sensing analysis and field observations of each of these litho-tectonic units.

\section{Geology of western part of Wadi Allaqi}

Umm Ashira and Tilal Al Qulieb area has been investigated in many field studies (e.g. El Shazly, 1964; El-Ramly, 1972, El-Shimi, 1992 \& 1996; EGSMA, 1996; El-Nisr et al.1996; Noweir et al., 1996 \& 2000; Abdul Aziz, 1999; Saleh and Abd El-Wahed, 2000; Ahmed, 2002; El-Afandy et al., 2007; Radwan, 2013; Shalaby, et al., 2019 and El Desoky et al., 2019).

The geology of the area is commonly described in terms of three major lithotectonic units, namely ophiolites, island arc assemblages, and syn- to late tectonic granitoid (EGSMA, 1996; Noweir et al., 1996 \& 2000; Kusky and Ramadan, 2002; Ahmed, 2002; Abdelsalam et al., 2003; Abdeen and Abdelghaffar, 2011; Abdel Rahman, 2013). According to the fieldwork of the present study mapping; the exposed basement rocks classified to four tectonic assemblages with eleven lithological units as follows:

\begin{tabular}{cll}
\hline Youngest & Dykes & (Rhyolitic-Dioritic-Basaltic) \\
\hline & Late- to post-tectonic & Granodiorite \\
& assemblage & Metagabbro-diorite complex \\
& Island arc assemblage & Metasediments including; schist, phyllite and marbles \\
& & Amphibolites \\
& & Pyroxenite \\
Oldest & Ophiolitic assemblage & Listwaenite \\
& & Talc carbonate rocks \\
& & Serpentinites \\
\hline
\end{tabular}

\section{Materials and Methods}

In this study, integration of Advanced Spaceborne Thermal Emission and Reflection Radiometer (ASTER) satellite images, structure features, field investigation and petrographic studies are used (Fig.2).

The aim of this study is re-mapping and identifying the lithological rock units around Wadi Umm Ashira and Tilal Al-Qulieb. Remote sensing plays an important role in the exploration of mineral deposits, and its capability in lithological mapping and detection of associated hydrothermal mineralization has been documented by numerous studies (Abdelsalam and Stern, 1996; Amer et al., 2012; Salem, et al., 2015; Abu El-Leil, et al., 2019; El Ghrabawy, et al., 2019; Zoheir, et al., 2019). For the lithological mapping various processing techniques were implemented, including False Color Composite (FCC), Color Ratio Composites (CRC) and Principal Component Analysis (PCA).

\section{I. Remote Sensing data (Aster Image)}

Advanced Spaceborne Thermal Emission and Reflection Radiometer (ASTER) imagery was used for lithological identification in the study area. ASTER level-1B data product was obtained from the Land Processes Distributed Active Archive Center (LP-DAAC) at NASA. ENVI (Environment for Visualizing Images, http://www.exelisvis.com) version 5.3 and ArcGIS version 10.1 software (Esri, Redlands, CA, USA) packages were used to process the ASTER imagery.

Several specific improvements were included to better ASTER's performance compared to existing optical sensors such as Landsat TM, SPOT HRV and JERS OPS: increased number of SWIR bands to six to improve mapping of surface composition.

1- Increased number of TIR bands to five to derive accurate surface temperature and emissivity measurements;

2- Improved radiometric accuracy and resolution.

3- Increased base-to-height $(\mathrm{b} / \mathrm{h})$ ratio of the stereo data, from 0.3 to 0.6 , to improve surface elevation determination. 
The Advanced Spaceborne Thermal Emission and Reflection Radiometer (ASTER) is a high spatial, spectral and radiometric resolution multispectral remote sensing sensor. The three subsystems of ASTER sensor, i.e. VNIR, SWIR and TIR has different roles to play in spectroscopy for geological applications such as the VNIR region provides spectral features of transition metals such as iron, SWIR region is very effective for analyzing spectral characteristics of carbonate, hydrate and hydroxide minerals, and TIR region is effective for characterization of silicates.

\section{I.1. ASTER image analysis}

\section{I.1.a. ASTER image pre-processing}

Pre-processing data free level 1B ASTER in hierarchical data format (HDF) that was acquired on 22 March 2003 was used for remote spectral analyses in this study. This image was pregeoreferenced to UTM zone 36 North projections with using the WGS-84 data. Preprocessing should be carried out to correct these errors to the maximum extent so that the inherent quality of the original information of the scene is detected appropriately. The outputs of the preprocessing which are available in the standard formats, either in photographic or digital are known as "data products". The pre-processing methodology is presented in the given flowchart (Fig.2).

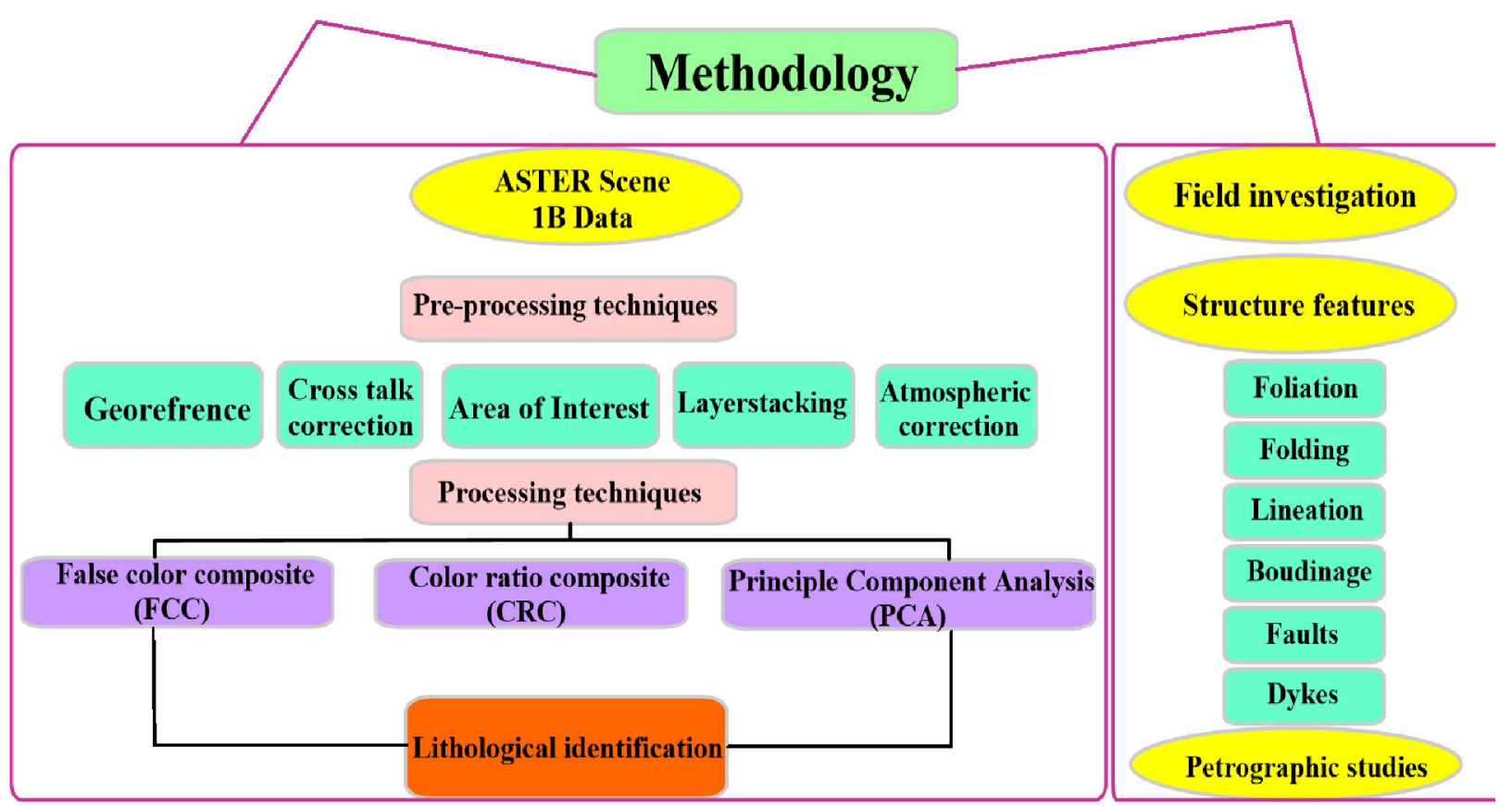

Fig. 2: Flowchart of methodology stages (ASTER data, field investigation, Structure features and Petrographic studies

Cross track illumination correction method was used to remove the effects of energy overspill from band 4 into bands 5 and 9. The SWIR bands should be corrected for cross track illumination effects before any further processing for better and accurate results. The ASTER Digital Elevation Model (DEM) of $30 \mathrm{~m}$ spatial resolution of the area has been used to derive average elevation of the terrain.

\section{I.1.b. ASTER Image processing techniques}

Various processing techniques were implemented for lithological mapping, including; False Color Composite (FCC), Color Ratio Composites (CRC) and Principal Component Analysis (PCA). A field verification was carried out to evaluate the derived lithological map and it shows good agreement with previously published map (Fig. 4). These image-processing techniques were used to characterize the lithology and structure of the area. 


\section{I.1.b.a. Color Composites images}

According to Vincent (1997) there are two types of color composites: True color composites and false color composites (FCC). False color composite (FCC), displays a color image which is suitable for geological analysis (Sabins 1997). The False color band combinations (b4, b5, b3) in RGB, (Fig.3 A) were selected for better visual interpretation and lithological discrimination of the rock units in the study area. On the other hand, color composite successfully discriminates biotite muscovite schist with a characteristic dark green color, while the metagraywacke and metatuffs show a pale green color (Fig.3 A). According to FCC image 4, 5 and 3 in (RGB) analysis of the studied area has a large open fold as well as the major left-strike slip fault and sigmoidal (augen) shape as a result of being affected by the Allaqi Heiani shear zone. The major strike slip fault is wadi Um Arka sinistral fault that run subparallel to Um Ashira major fault that led to lateral movement of metasediment (pale green) and the marble bands (pink color) horizontal displacements of about $100 \mathrm{~m}$ to 747 m (Fig.3 B). Restraining bend structure (sigmoidal=augen shape: Fig.3 C) formed result of a sinistral fault (Fossen, 2010).

\section{I.1.b.b. Color Ratio Composites (Band ratio)}

Color Ratio Composites or Band ratio is a useful technique to enhance spectral differences between bands and to reduce topographic and illumination effects (Gao, 2008). Calculating band ratio is simple. Dividing the brightness values (DNs) at peaks/maxima and troughs/minima in a reflectance curve will elevate the DN values of specific geologic materials and may enhance the contrast between them. The choice of bands based on their spectral reflectance and the absorption features of the mapped mineral. The ASTER band ratio image (bands 4/7, 3/4, 2/1 in RGB respectively) that has been originally prepared for alteration zone mapping has been found to be the most successful image used to highlight the lithological boundaries in the study area. This ratio is equivalent to Abram's ratio $(5 / 7,4 / 5,3 / 1)$ of Landsat TM (Abrams et al., 1983) which used by (Abdeen et al., 2001) for mapping serpentinite, granite and marble units of the Neoproterozoic Allaqi Suture in the southern Eastern Desert of Egypt (Fig.4).

The Second band ratio composite $(4 / 1,6 / 2,8 / 2)$ for RGB is considered the best band ratios which separated between the different rock types in the study area especially, serpentinites, talc carbonate and marble (Fig.5). It is showing the major fold structure in the central part of the area.

\section{I.1.b.c. Principal Component Analysis}

Multispectral images often have similar visual appearance for different bands, which cause data redundancy. Principal component analysis (PCA) is a general method of analysis for correlated multivariable datasets by mathematical transformation of the original data which are arranged according to the axis of greatest variability for creating new non-correlated components. Principal Component Analysis technique resulted the best three PC combinations of ASTER.

PCA displays the maximum contrast from several spectral bands with three primary display colors, (Vincent, 1997). We found that (PC3, PC1, PC4 in RGB) enhances the main structural trends affecting the area under investigation (Fig. 6). Also, the images (PC4, PC2, PC1 in RGB) and (PC3, PC1, PC4 in RGB) comprise most of the various lithologic types in the area (Fig. 7\&8). Both images were good for lithological and structural edge enhancements for both visual interpretation and field mapping.

\section{II. Field Investigation and Geological Setting}

More than 100 rock sample has been collected through a field trips to wadi Umm Ashira and Tilal Al Qulieb.

\section{The Ultramafic rocks}

The ultramafic rocks represent the oldest rock unit in the study area (Akaad and Noweir, 1980). The exposed ultramafic rocks observed in the southern part of Tilal Al-Qulieb and comprise dismembered serpentinites, talc carbonate rocks, listwaenite, and amphibolite as well as minor outcrops of pyroxenite. 


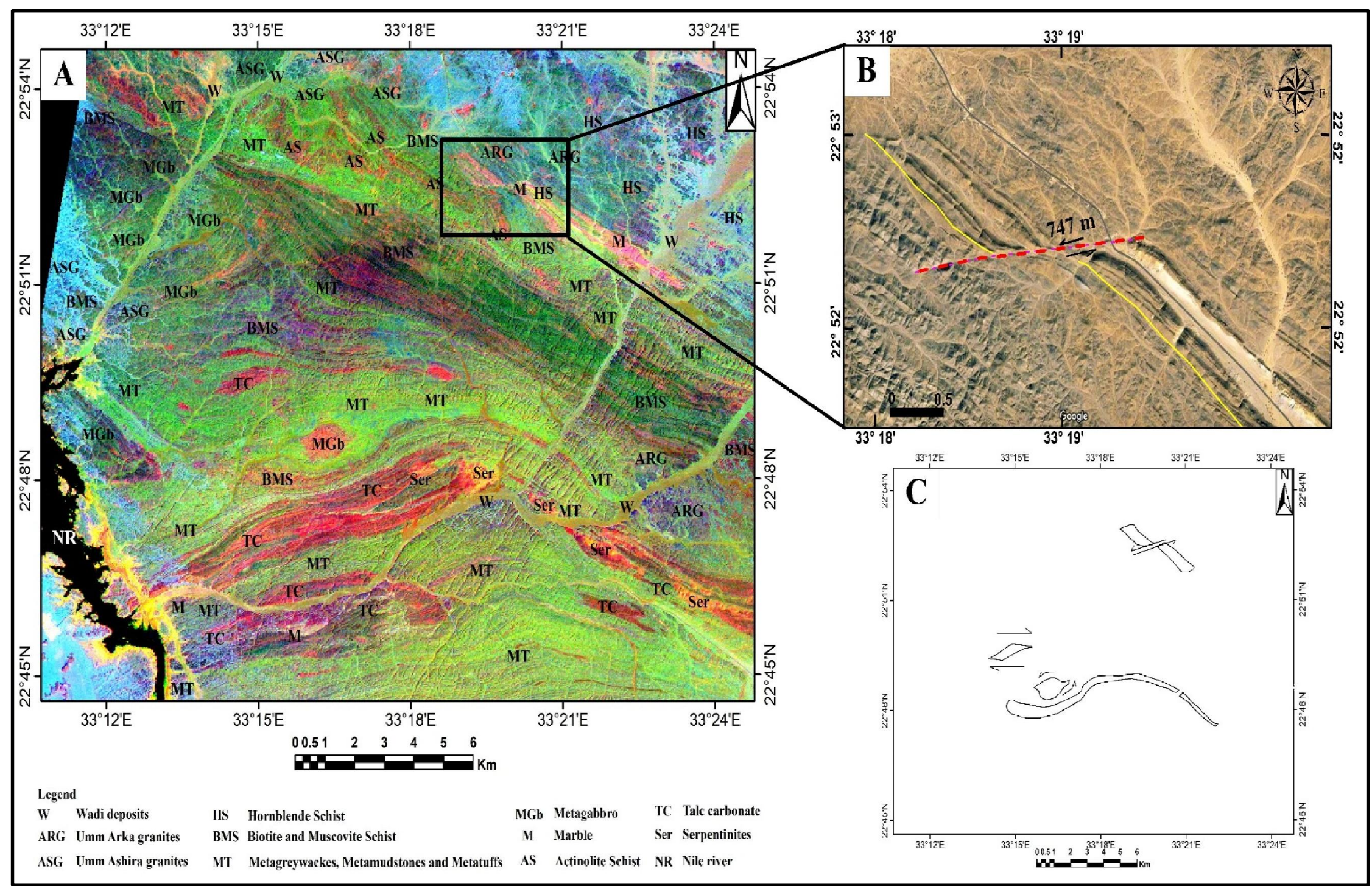

Fig. 3: a- ASTER FCC image 4, 5 and 3 in (RGB) respectively. b- Satellite images for evidence of major strike slip fault is wadi Um Arka. c- Augen-shaped (sigmoidal) structure and open fold within the high-strain zone of Allaqi area indicating sinistral sense of shear. 
Curr. Sci. Int., 10(4): 485-504 2021

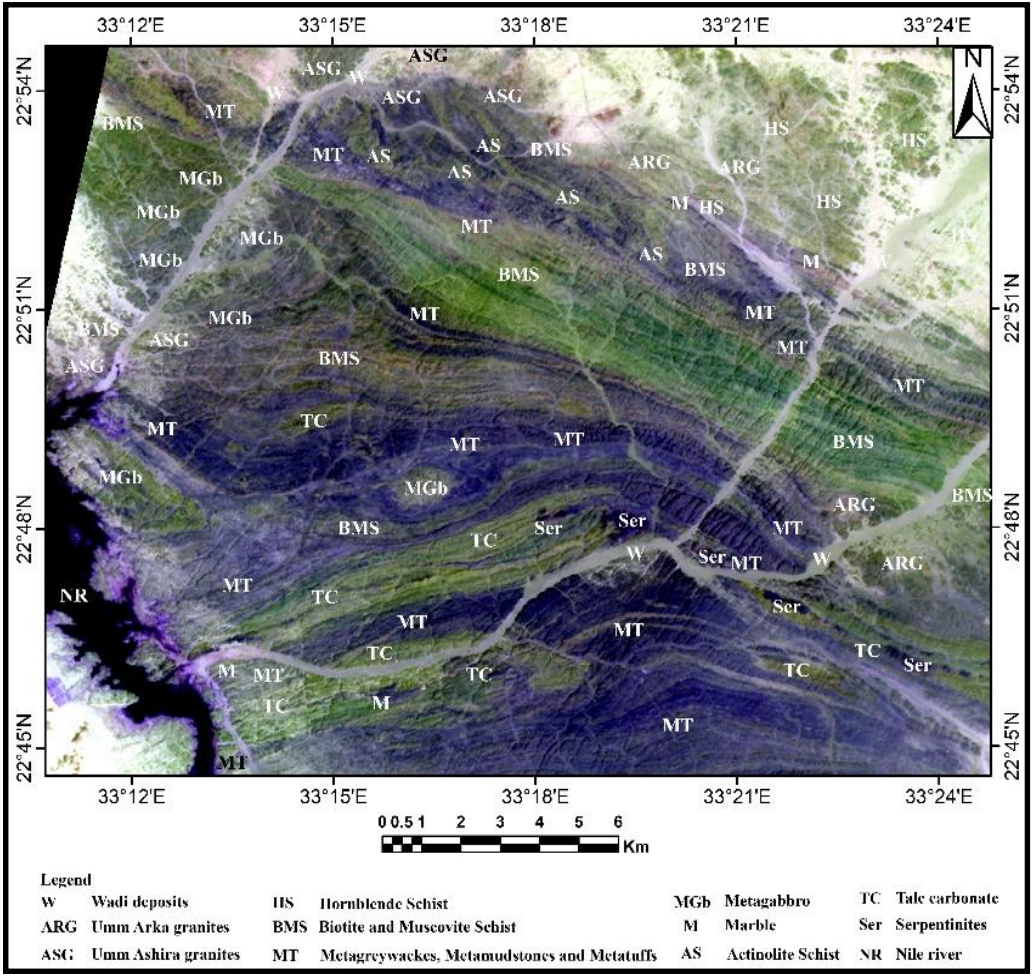

Fig. 4: ASTER band ratio (4/7, 3/4, 2/1) RGB (modified after Abrams et al., 1983).

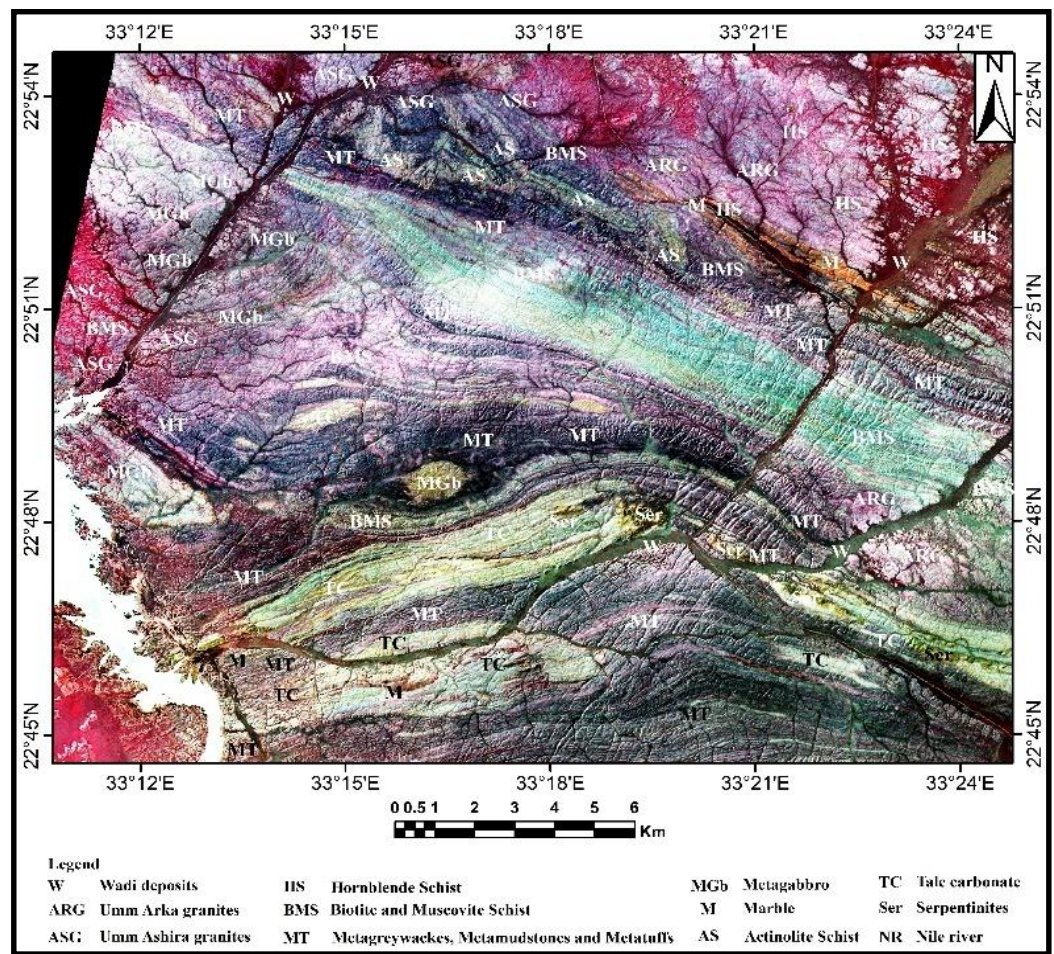

Fig. 5: ASTER band ratio (4/1,6/2, 8/2) RGB respectively. 
Curr. Sci. Int., 10(4): 485-504 2021

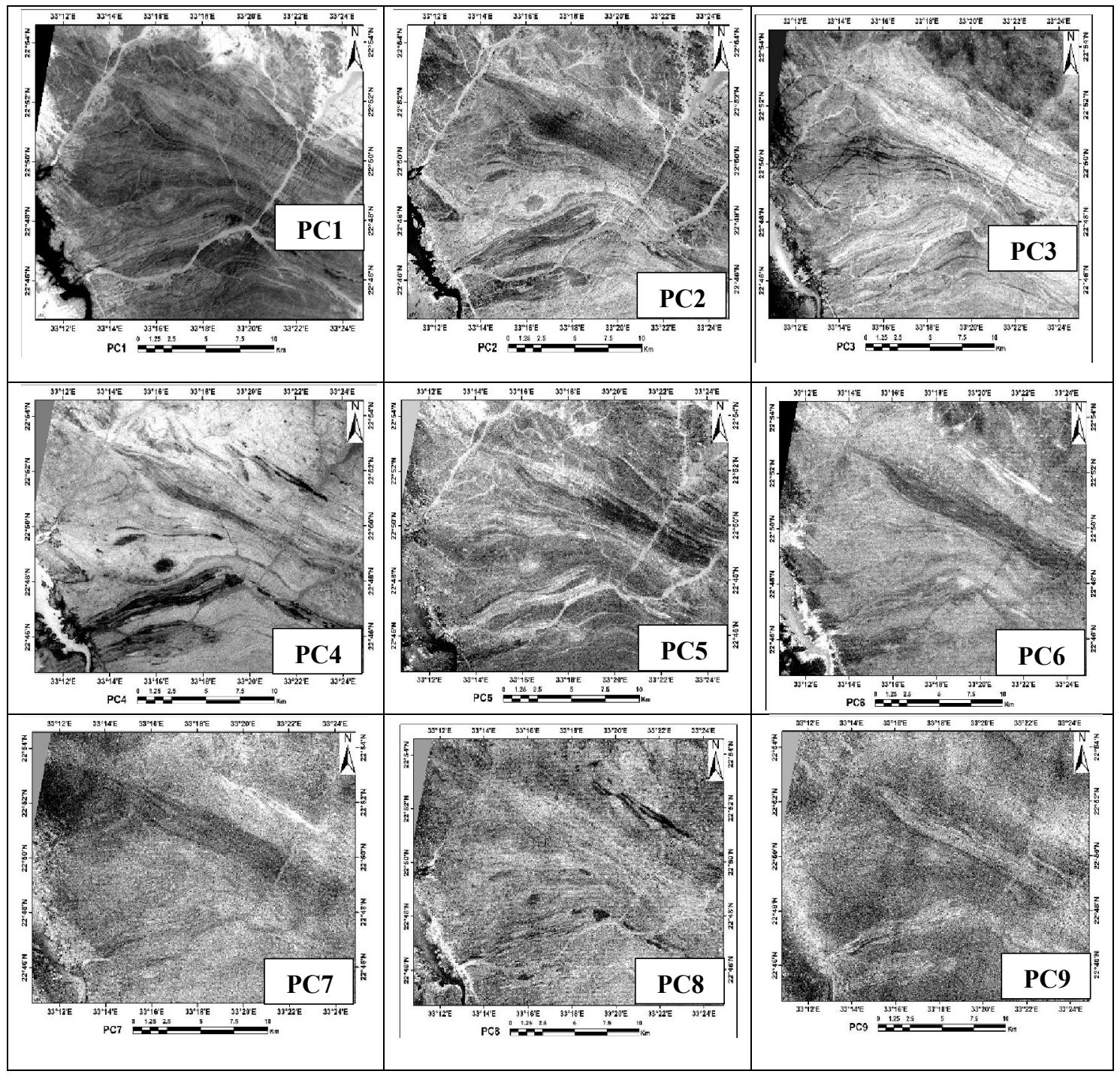

Fig. 6: Comparison of PCs bands.

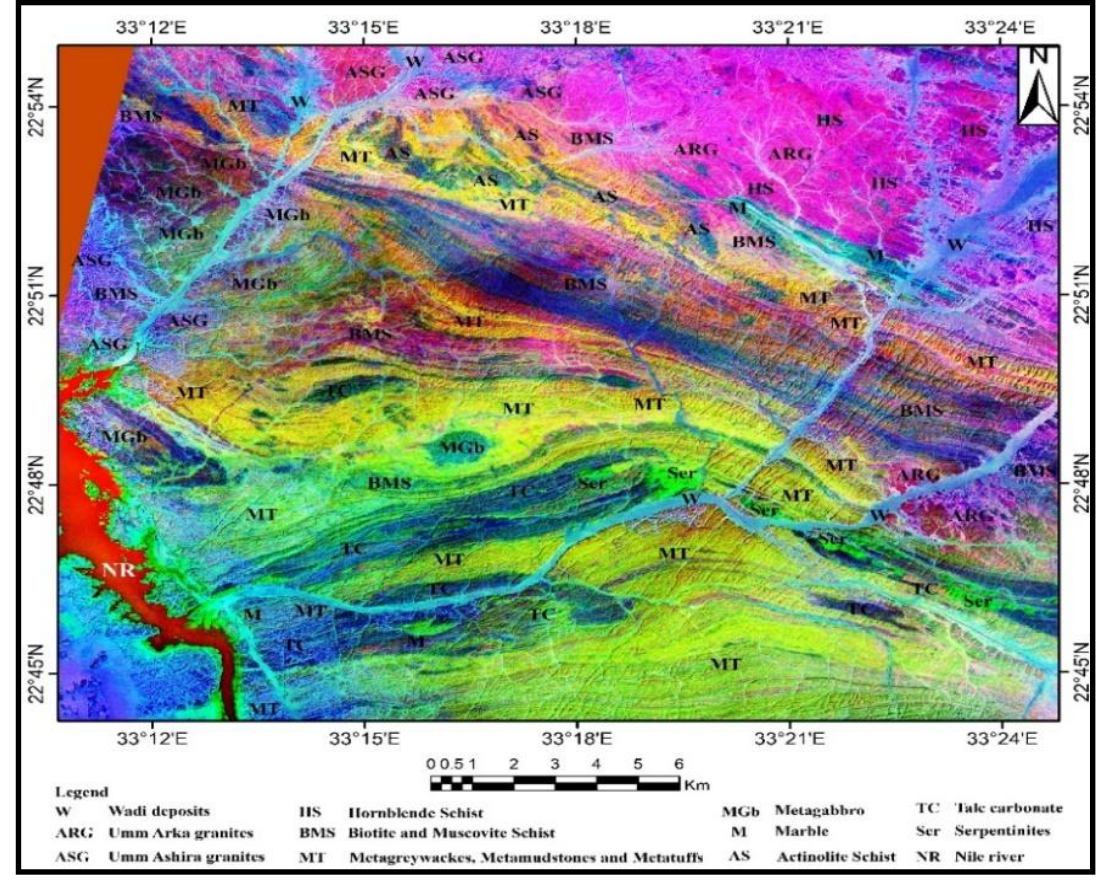

Fig.7: PCA (PC3, PC1, PC4 in RGB) image. 


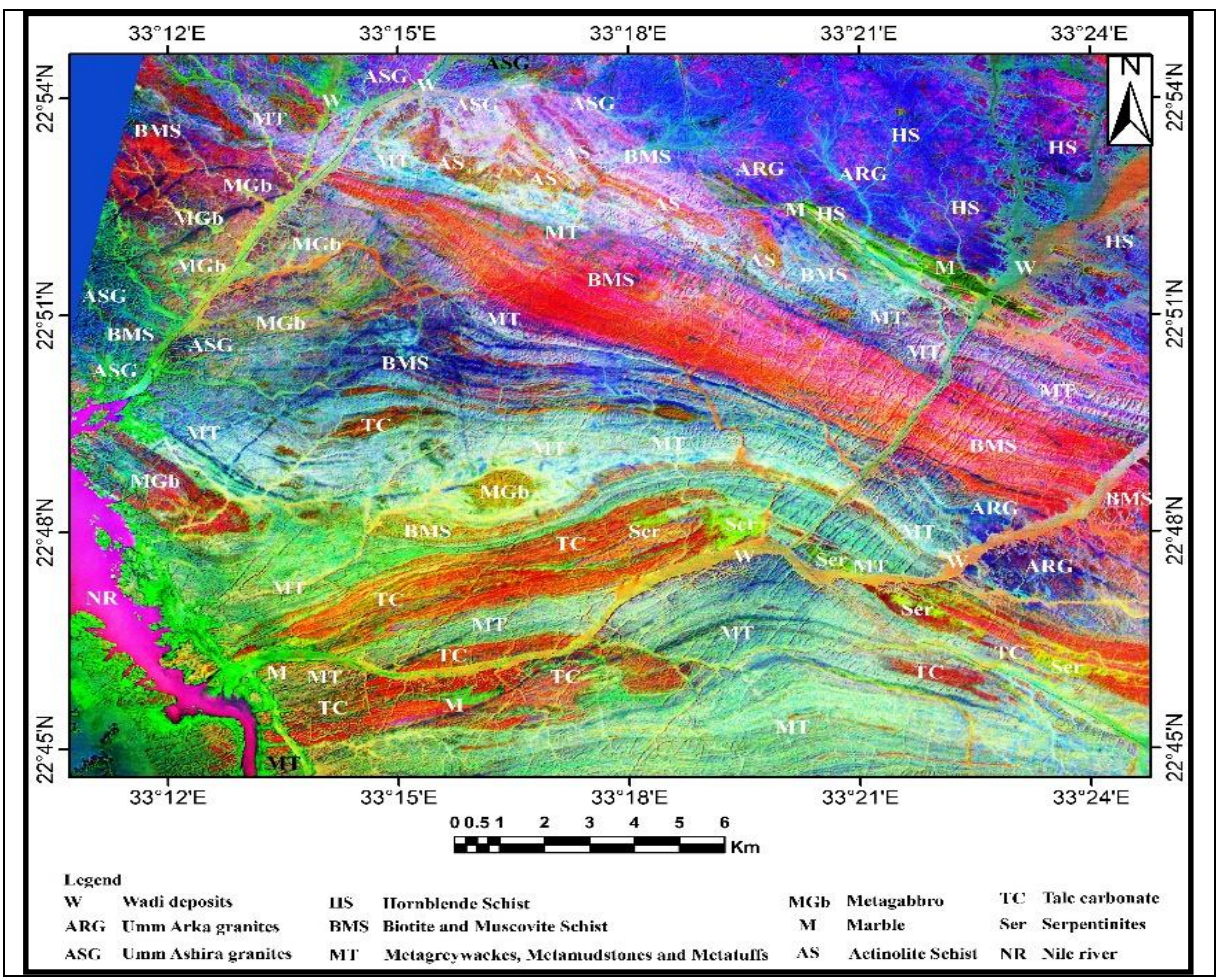

Fig. 8: ASTER PCA (PC4, PC2, PC1 in RGB) image.

\section{The Serpentinite rocks}

The serpentinites occupy large areas and form conspicuous mountainous ridges with steep slopes. The serpentinites rocks are generally massive but become sheared along the shear zone (Fig.9 A). The contacts between the ultramafic and adjacent rocks are sharp and distinct.

\section{Talc-carbonate rocks}

Talc-carbonates are observed as creamy to greyish in color, soft in touch and variably cavernous. The talc- carbonate rocks occur as large patches scattered irregularly within the serpentinites.

\section{Listwaenites}

The most characteristic feature of listwaenite its white to brownish color and porous texture (Fig.9 B \& C). The reddish-brown surface appearance is ascribed to oxidation of Fe-bearing carbonates to iron oxides. The listwaenites rocks in Tilal Al Qulieb are distinguished into two main types: i) silica-rich listwaenite, and ii) carbonate-rich listwaenite.

\section{Pyroxenites}

Pyroxenites occur as unmappable pockets, lenses or shear pods within the ultramafic rocks. These rocks occur as a dark grey to black colored masses, of fine- to medium-grained crystals.

\section{Amphibolite}

The amphibolite rocks are unmappable massive, fine-grained to medium, black to dark green color and commonly foliated (Fig.9 D). Amphibolites in the studied district are transformed from metaigneous rocks along the marginal zones. Foliation is the result of the preferred alignment of amphibole minerals and the alternating amphibole and plagioclase-quartz rich layers. 

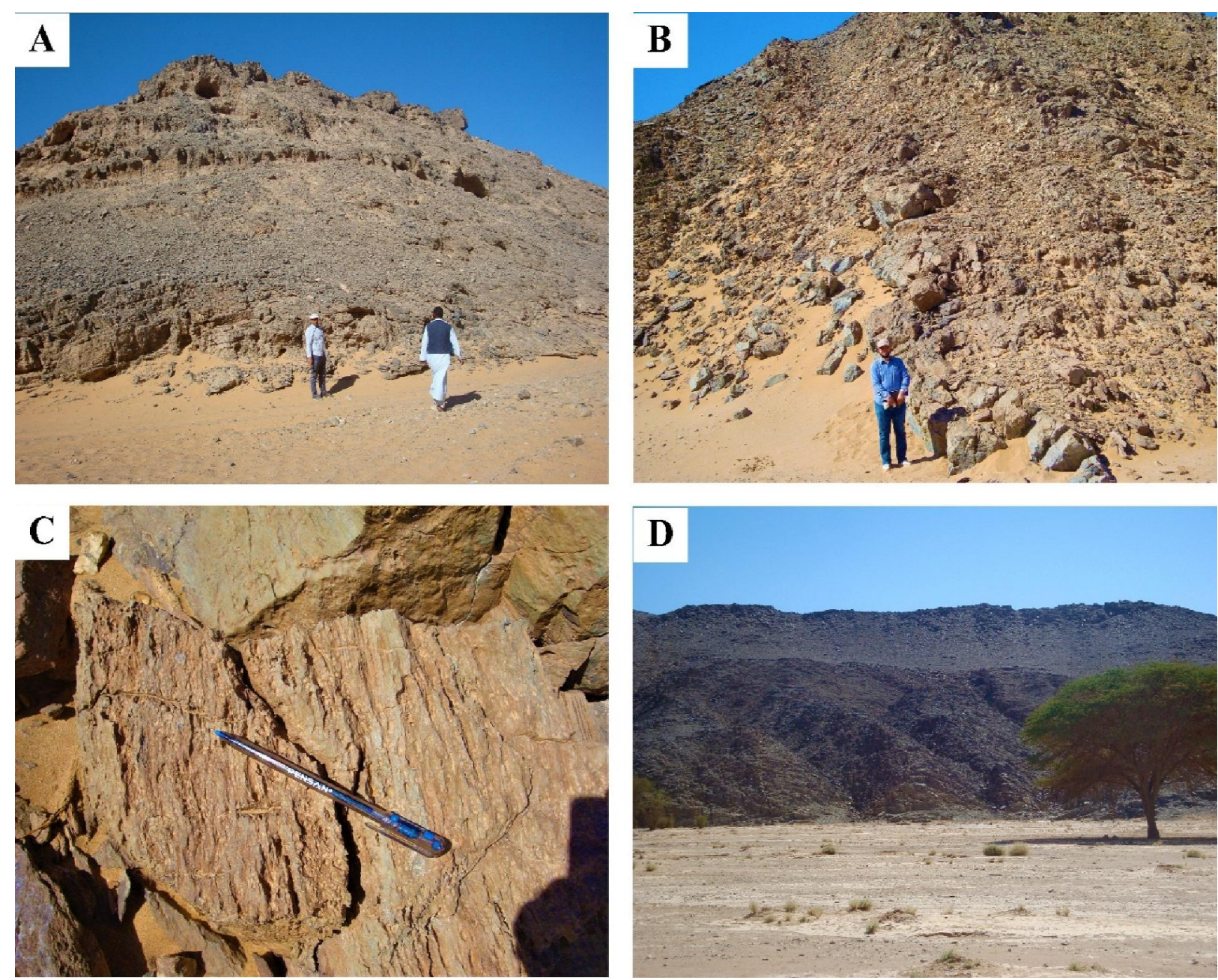

Fig. 9 : a- Photograph showing sheared serpentinites of Wadi Tilal Al-Qulieb. Looking NW. bPhotograph showing listwaenite at Tilal Al- qulieb area. Looking W-E. c- Photograph showing massive and porous listwaenite rocks. d-Photograph showing amphibolite rocks forming folded sheet-like bodies. Looking E-W.

\section{Metasediments}

These rock units cover the greater part of the mapped area. These rocks comprise schists with narrow quartzitic bands, phyllite, and marble. Well preserved graded bedding and other primary structures are still preserved. The metasediments are intrusive contact with granitic rocks. These rocks are usually of high schistose most often due to the action of the over thrust bodies.

\section{Schists and Phyllite.}

Schist rocks commonly occur in low relief and highly schistose rocks. These rocks are foliated and highly sheared as a chevron structure. Folds of the metasediments in the Wadi Tilal Al -Qulieb area are best exemplified by the folds formed essentially by highly schistose metasediments (Fig.10 A). It is a result of compression affect folding (anticline and syncline) with chevron structure (Fig.10 C\&D). The phyllite is greenish in color, strongly foliated (Fig.10 B) and characterized by pencil structure (Fig.10 E). These rocks are vertical to sub-vertically layered dipping $80^{\circ}$.

\section{Marbles}

The largest marble exposures were recorded in Wadi Um Arka area. They form high ridges about $25 \mathrm{~m}$ in height and the average width of $200 \mathrm{~m}$. The marbles are observed in the area as inverted layers (vertical level) of variable thicknesses interbedded with the schists at the east of Tilal AlQulieb and to the north of Wadi Shukayyat (Fig.10 F\& 11 A). In the eastern part of Tilal Al-Qulieb schists are contacted tectonically with marble rocks (Fig.10 F\& $11 \mathrm{~A}$ ). 

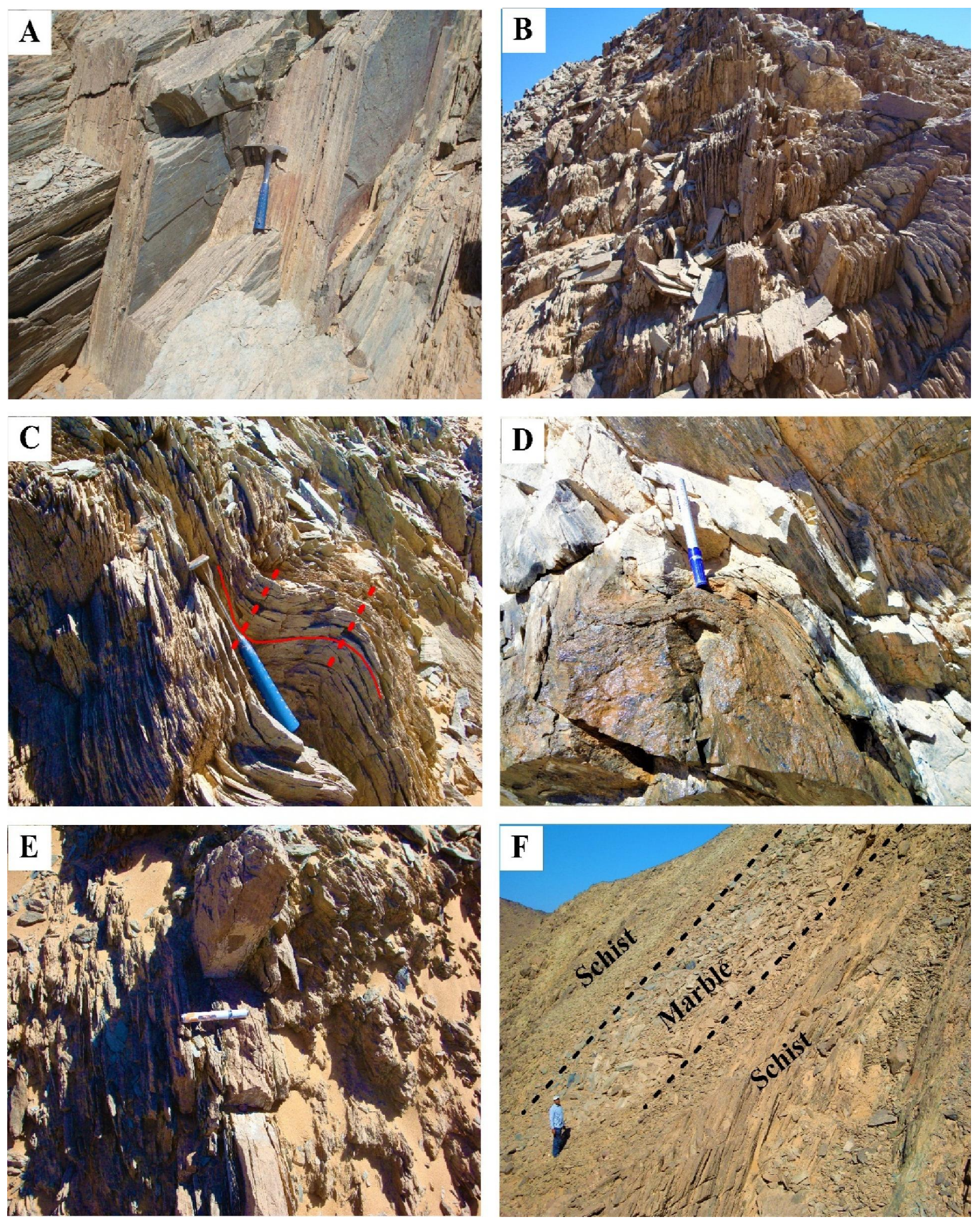

Fig. 10: a\&b- Well developed vertical foliation and jointed the schists and phyllite in Wadi Tilal AlQulieb. Looking E-W. c- Chevron structure in schists result of compression affects folding (anticline and syncline). Looking E-W. d- Mesoscopic folds showing intrafolial fold in schists in Wadi Umm Ashira. e- Pencil structure in phyllite rocks. f- Vertical layered of schist and marble in northWadi Shikayit. Looking (E-S). 

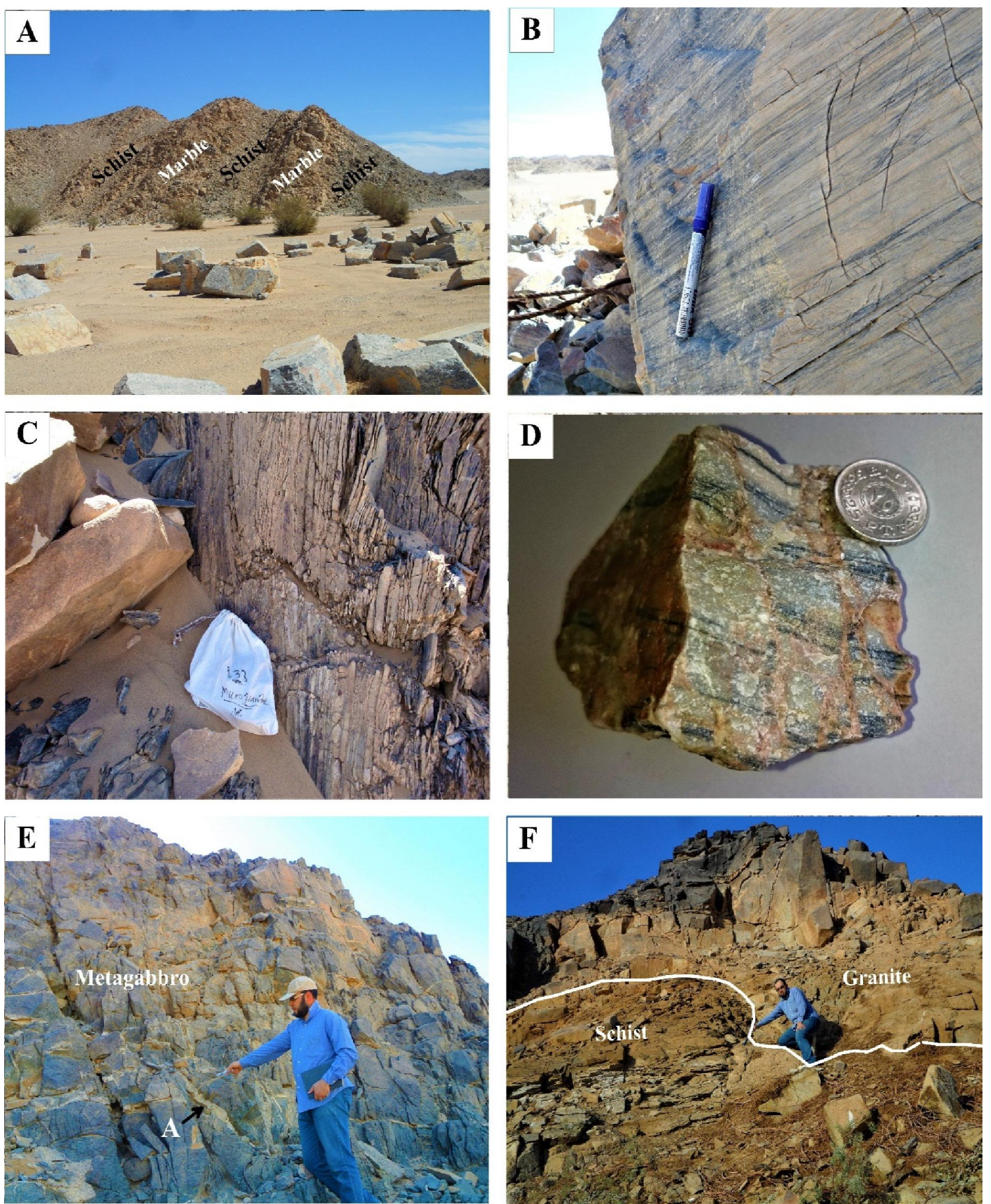

Fig. 11: a-Thick layers of marble interbedded with schists in east wadi Tilal Al-Qulieb. Looking NE. b- Well-developed banding in marble east Wadi Tilal Al-Qulieb (Wadi Umm Arka). c- Boudinage structure in layer schist. d- Mezostructure of faults in grey marble at Wadi Umm Arka. e- Thin aplitic dyke (A) observed within the metagabbro (MG). Looking SE. f- Intrusive contact between granodiorite and highly sheared schists at Wadi Umm Ashira Looking NW.

Two main types of marbles are recorded; white marble and grey marbles. White marble outcrops as thick layers over 20 meters interbedded with schists. White marble reflects the absence of impurities besides the high percentage of calcareous materials. The grey marbles are highly elevated hills overlain by the schists. It is usually banded range from a few millimeters to 5 centimeters in 
width. Black marble reflects the presence of disseminated graphite or biotite beside a low percentage of calcareous fraction in the schists is also observed (Fig. $11 \mathrm{~B}$ ).

\section{Metagabbro-diorite complex}

The metagabbro-diorite occupy the eastern and western parts of Umm Ashira area. On the other hand, the metagabbros are mainly contained xenolithic along the contact zones and invaded by aplitic dykes and rhyolitic dyke (Fig.11 E).

\section{Granodiorite}

These rocks are exposed as separated, exfoliated masses e to intensive vertical and lateral joints pointing to structural deformation effect. At the western side of Wadi Umm Ashira, the granodiorites masses exposed in intrusive contact with the highly sheared schists (Fig. $11 \mathrm{~F}$ ).

\section{III. Structural Features}

The structural patterns are interpreted as the result of the fieldwork and analysis of the ASTER images. The structural features comprise the ductile (foliation, folding, lineation, and boudinage structures) and brittle features (faults and dykes).

\section{III. 1- Ductile Structure Deformations}

a. Foliation

Foliations are one of the most common features throughout the area. Foliations represent the areas of no deformations at which original sedimentary structures are still preserved, it is found parallel to the main bedding planes. The best foliation recorded in the schists and phyllite (Fig.10 A\&B). They vary from non-penetrative to penetrative fabrics and are mainly represented by axial plane and crenulation foliation.

\section{b. Folding}

The imprints of folding structure in the studied district are well exhibited by the metamorphic rock units, especially the metasediments where they are principally expressed by major and minor folds. Folds of the metasediments in the Wadi Tilal Al -Qulieb area are best exemplified by the folding formed essentially by highly schistose metasediments. It is a result of compression affect folding (anticline and syncline) with chevron structure (Fig.10 C \& D).

\section{i-Major Fold}

They are differentiated into major (macroscopic) and minor (mesoscopic) ones. The major folds range in length of their axial traces from 4 to $18 \mathrm{~km}$ (Fig.3C \& 13). The minor folds are extremely developed along the main foliation and within the limbs and hinges of major folds. Their axial traces vary in distances from $2.2 \mathrm{~km}$ to some of millimeters.

The most important of these folds is outlined in the central part; extending from Wadi Heisurbah passing in the northwestern direction across Wadi Umm Arka to the tributaries of Wadi Ashira for a distance of about $18 \mathrm{~km}$ (Fig.13). The axial plane of anticlinal fold-oriented NW-SE and is plunging with a moderate angle to SE. The fold shows a gentle plication in the ENE direction; onsetting of a later deformation. The folding of this deformation exhibits a wavelength of about $10 \mathrm{~km}$ and a steep angle in the same direction (Noweir et al., 1996).

Going east of the map at the junction of Wadi Umm Arka and Wadi Tilal Al Qulieb, the main foliations plicate to outline an open anticlinal fold plunging with a steep angle towards ENE. The buckling of this fold is amplified and developed with a high wavelength/amplitude ratio (Fig.3C \& $13)$.

\section{ii- Minor Fold}

These folds are developed in styles of very tight, chevron and open folds (Fig.10 C \&D). They have axes and axial planes parallel to those of major folds. 


\section{c. Lineation and Boudinage structures}

Well-developed stretching lineation defined by stretched mineral aggregates including quartz, chlorite, and biotite is observed on the foliation planes of the metasediments. Lineation may be represented by the minerals elongation boudins structures of variable sizes such as graphite bands within grey marble (Fig.11 B). The long axis of the boudins usually run subparallel to the main schistosity with a small angle of rotation at rare sites (Fig.11 C).

\section{III.2. Brittle Structure Deformation \\ i- Faults}

According to our fieldwork, remote-sensing studies and the previous work after Noweir et al., 1996; the faults are considered the main factor of brittle essentially categorized into thrust and strikeslip ones. The thrusts are WNW-ESE to NW-SE and defined the contact between the hanging wall ultramafic rocks and their highly sheared derivatives from the footwall amphibolites, metasediments and metatuffs. The thrust fault is located in the central part and defines the contact of the ultramafic rocks and their highly sheared derivatives from the underlying metasediments, metatuffs (Fig. 13). The dip of their planes faces to NE with angles $45^{\circ}$ to $65^{\circ}$ but locally it varies between $30^{\circ}$ and $45^{\circ}$. These faults are characterized by cataclasis, intensive shearing and marked by narrow zones of mylonite and talc to sheaths of asbestos and magnesite veinlets (Fig. $3 \mathrm{C}$ ).

The strike-slip faults, on the other hand, are extended ENE-WSW to NE-SW. Approximately, they have rectilinear manner, parallel the axial traces of major folds and constrain the trends of main wadis and tributaries (e.g. Wadi Umm Arak). The main fault of this type is a sinistral fault that bisects the area into two western and eastern parts with major NNE-SSW trending and extends to about 14 $\mathrm{Km}$ length and displaced and forms the main Um Ashira wadi. The grey marble occurs as clearly oriented mineral bedding has showing mezofault in east Tilal Al-Qulieb (Wadi Umm Arka; Fig.11 D). The major strikep-slip fault is wadi Um Arka sinistral fault that runs subparallel to Um Ashira major fault that led to lateral movement of metasediment (pale green) and the marble bands (pink color) horizontal displacements of about $100 \mathrm{~m}$ to $747 \mathrm{~m}$ (Fig.3 B). Restraining bend structure (sigmoidal=augen shape) formed a result of a sinistral fault(Fig.3 B; Fossen, 2010).

\section{ii-Dykes}

Dykes of basic, intermediate and acidic varieties dissected the area. They are widely distributed in the area of study; they differ in their lithologies and also in their orientations and relations with the country-rock. They have different composition and thickness, as well as they are more resistant than the country rocks. The main trends of dykes are NW-SE, ENE-WSW and NNE-SSW directions.

\section{a. The acidic dykes}

These dykes are represented by rhyolite dyke form ENE-trending sets in Umm Ashira area. In hand specimen, they are pale green and pink colored, porphyritic, with feldspar phenocrysts (Fig.12 A $\& B)$.

\section{b. The basic dykes}

These dykes are common in the western part of the Umm Ashira area cutting metagabbrodiorite and grade to basaltic composition. They have black color, but mostly covered by greyish weathering surface (Fig.12 C).

\section{c. The intermediate dykes}

It is occurred in the south Tilal Al-Qulieb and extending to the north of wadi shukayyat. These dykes are black in color and grade to microdioritic composition (Fig.12 D).

By using all a above techniques like fieldwork, structural relationships, principal component analysis images, and band ratio from ASTER image to compare the geological map of the study district with the previously published map (Noweir et al., 2000). The different geological and structural studies and ASTER images of the study district were used to draws the geological and structural mapping (Fig.13). The new modified map is more accurate and good discrimination between the different rock units in the study district and shows for structure features (Fig.13). 


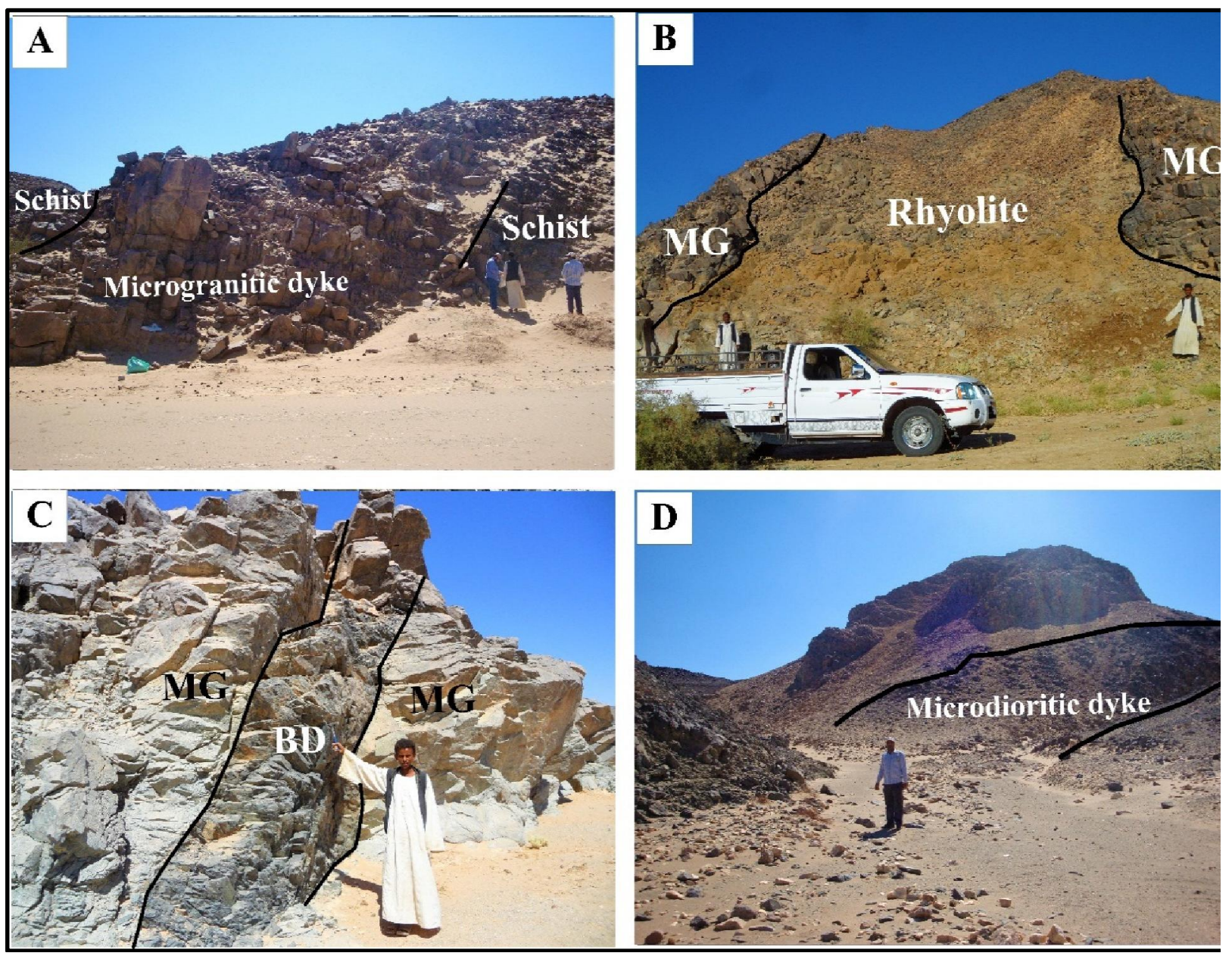

Fig.12: a- Vertical jointing of a microgranitic dyke intruding the schist of wadi Tilal Al Qulieb. Looking (E-W).b- Metagabbro (MG) intruded by (porphyritic rhyolite dyke) at Wadi Umm Ashira. Looking (NW). c- Basic dyke (BD) intruding the metagabbro (MG) in Wadi Umm Ashira. Looking (E-W). d- Microdioritic dyke in wadi Tilal Al-Qulieb. Looking (W-E). 


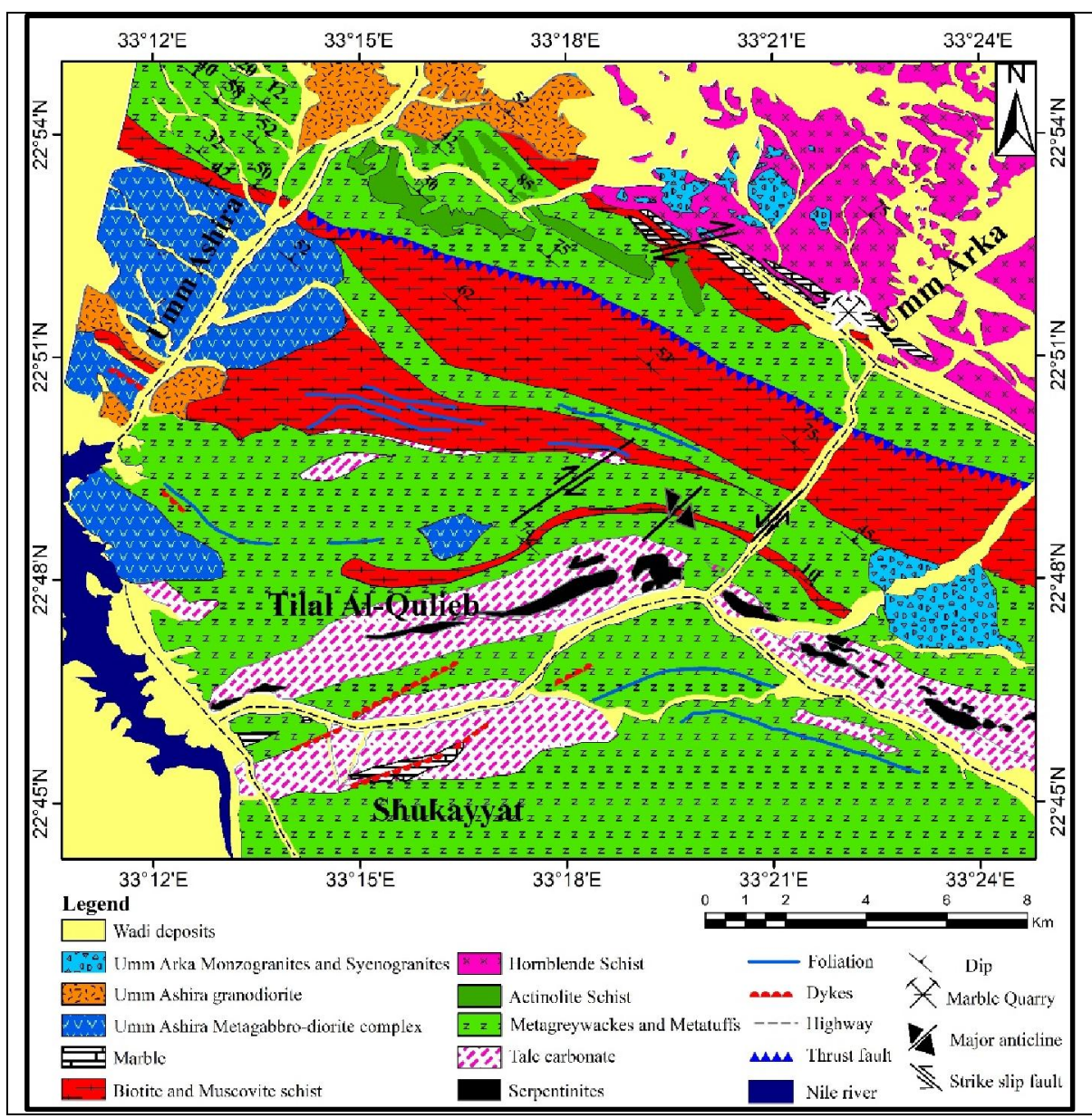

Fig. 13: Final lithological map of Wadi Tilal Al-Qulieb and Wadi Um Ashira area modified after Noweir et al., (2000).

\section{Petrography of deformed rocks}

1-Serpentinite rocks consist of serpentine minerals with a minor amount of carbonates and opaque minerals (chromite). The serpentine minerals are represented mainly by antigorite and chrysotile. Antigorite often occurs as colorless, flaky, xenomorphic in feather-shaped aggregates and sometimes as elongate blades with a roughly parallel arrangement. Carbonates formed as an alteration product of serpentine minerals (Fig.14 A). They appear as colorless fine-grained aggregates or patches. In some parts, carbonates coalesce to form bent veinlets results of deformation (Fig.14 A).

2- Amphibolite The rocks are essentially formed of Tremolite-actinolite associated with hornblende, calcite. Tremolite-actinolite exhibit prismatic, columnar and fibrous crystals and brownish blue color (Fig.14 B). Calcite is colorless with distinct two sets of cleavage, showing good twinkling. Immature carbonate crystals were displayed as fishsigmoidal and mylonitic shape (Fig. 14 B).

3-Listwaenite rocks are a massive, reddish brown color and fine-grained rocks. The rocks consist mainly of carbonate and subordinate amounts of quartz. Quartz appears as sheared anhedral to subhedral crystals with undulose extinction. These rocks exhibit granoblastic and mylonitic texture (Figs.14 C). Calcite characterized by twinkling and ranged from fine-grained to very coarse grain. It classified into two types: mature and immature crystals.

4- The schists are fine to coarse-grained and well-foliated rocks. It composed of quartz, biotite, muscovite, garnet and sillimanite. Chlorite, carbonate and opaque minerals are common accessories. It characterized by highly schistose and mylonitic texture. Mineralogy of these rocks includes mineral phases pointing out to medium or high-grade metamorphism (biotite \pm hornblende, garnet + rare sillimanite). Quartz occurs as allotriomorphic xenoblastic crystals and granoblastic crystals and bands parallel to the schistosity. Some crystals characterized by augen structure (Fig.14 D). Biotite porphyroblasts are attenuated in the direction of shearing to form a 
distinctive shape known as mica fish (Fig.14 E). Garnet crystals are idioblast crystals. Garnet crystals are frequently broken down to an aggregate of smaller crystals. Garnet occurs as pretectonic crystals that form shattered (Fig.14 F).

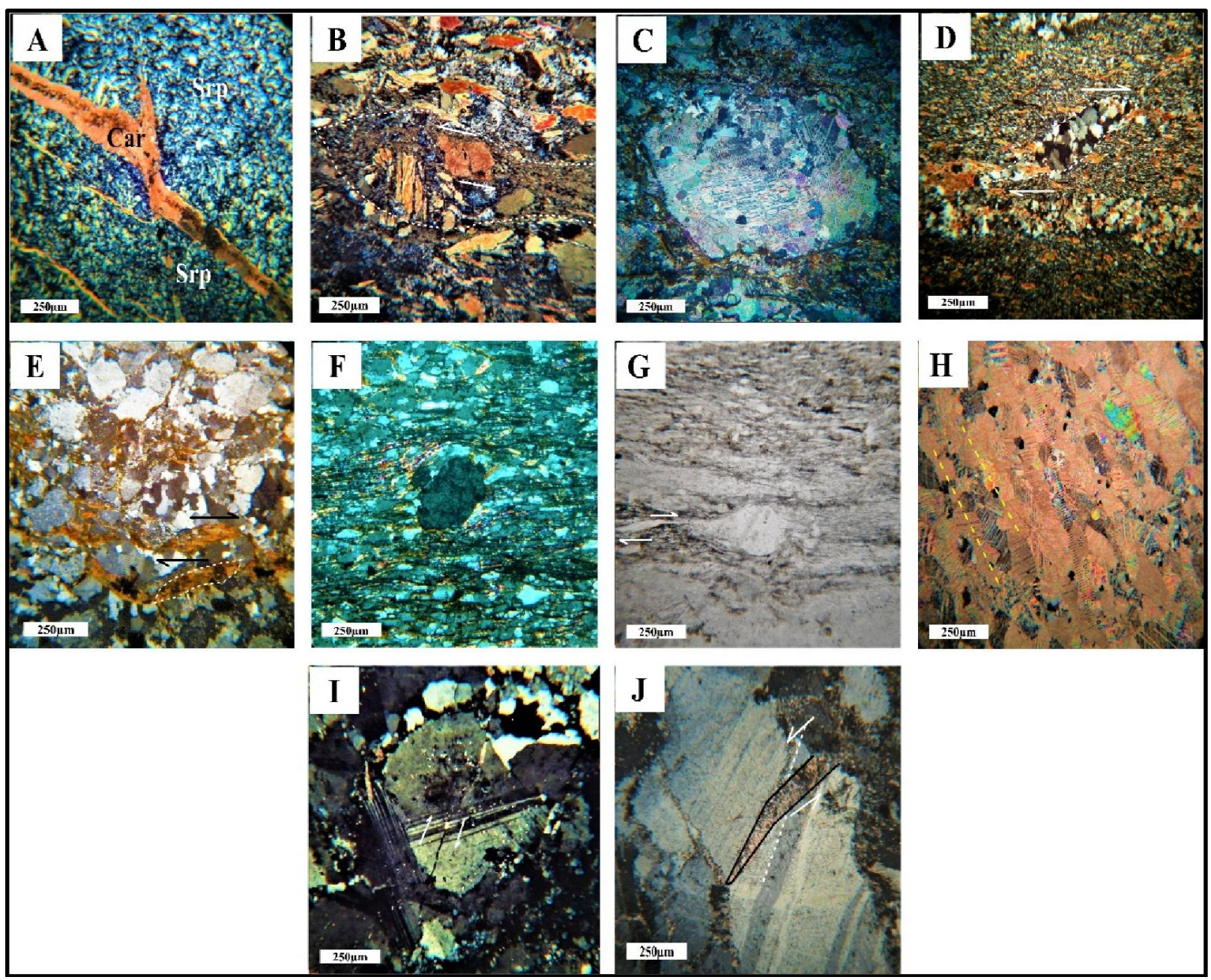

Fig. 14: Photomicrograph showing (A) bent of carbonate result of deformation. CN.10x4. (B) sigmoid fish of immature carbonate (Car) and mylonitic texture in amphibolite. C.N., X 10/4. (C) mylonitization of larger carbonate in listwaenie rocks. C.N.X10/10. (D) sigmoidal polygonal quartz aggregate and biotite with a preference orientation. C.N., X 10 / 4. (E) sigmoid biotite fish in garnet biotite quartz schist a. C.N. (F) lenticular garnet porphyroblast grew initially syntectonically leaving behind its sigmoid fish with tails of biotite crystal. P.P.L., X 10/10. (G) porphyroclast derived from a narrow shear zone transecting a weakly deformed phyllite with graphite (Gr). P.P.L., X $4 / 10$. (H) orientation of carbonate crystals. C.N., X $4 / 10$. ( $\varphi$ ) (I) slightly displacement of plagioclase (Pl) crystals result of deformation. C.N., X 4/10. (J) slightly displacement of plagioclase (Pl) crystals result of deformation. C.N., X 4/10.

5. Phyllite These rocks are composed essentially of quartz, micas (dominantly sericite and muscovite), graphite, carbonate minerals, and opaque minerals are the main accessories. These rocks are characterized by the well-developed cataclastic textures which are more intense along the major thrusts and lead to the formation of mylonites (Fig.14 G). Porphyroclasts are single crystals of a size exceeding the mean grain size in the surrounding matrix and typical for mylonites. Porphyroblasts are a valuable source of information on local tectonic and metamorphic evolution, in special cases also as shear sense indicators. Quartz phenocrysts have resisted the deformation more than the former groundmass. Phi clasts type porphyroblasts $(\varphi)$ : Ongoing 
deformation and rotation of a sigma-clast may lead to a more symmetric structure, without any step (Fig.14 G).

\section{6- Marble Rocks}

These rocks are fine- to coarse-grained and commonly characterized by the presence of welldeveloped carbonate minerals. It shows equigranular, granoblastic texture. It is composed essentially of a mosaic of equant anhedral grains of carbonate minerals (calcite and dolomite). The orientation of carbonate crystals is indicator on effects of pressure (Fig.14 H).

\section{7- Rhyolitic dykes}

Microscopically, this rock type is composed essentially of plagioclase, quartz, potash feldspar (microcline and orthoclase) and biotite. Hornblende, muscovite, allanite, sphene, and are the accessory minerals. Chlorite and sericite are alteration products of biotite and plagioclase. Plagioclase appears as medium-grained subhedral crystals. These crystals have slightly displacement result of deformation and saussuritized (Fig.14 H \& I).

\section{Conclusion}

The basement complex in the studied area comprises ultramafic rocks, metasediments, metagabbro-diorite, granodiorite and dykes. The main target of the present studied integrating remote sensing and fieldwork to identifying the lithological rock units and structural features around Wadi Umm Ashira and Tilal Al-Qulieb in the northwestern segment of Wadi Allaqi, South Eastern Desert of Egypt.

The lithological mapping several processing techniques were applied on ASTER data, including; False Color Composite (FCC), Color Ratio Composites (CRC) and Principal Component Analysis (PCA).

The False color band combinations (b4, b5, b3) in RGB, were selected for better visual interpretation and lithological discrimination of the rock units in the study area. The band ratios composite $(4 / 1,6 / 2,8 / 2)$ and $(4 / 7,3 / 4,2 / 1$ in RGB respectively) for RGB is showing a good band ratio which separated between the different rock types in the study area especially, serpentinites, talc carbonate, and marble. Three of the Principal Component Analysis technique of ASTER (PC3, PC1, PC4 in RGB respectively), (PC2, PC3, PC1 in RGB respectively) and (PC4, PC2, PC1 in RGB respectively) enhances the main structural trends affecting the area under investigation. These images consider good for lithologic and structural edge enhancements for both visual interpretation and field mapping. According to FCC image 4, 5 and 3 in (RGB) analysis of the studied area has a large open fold as well as the major left-strike slip fault and sigmoidal (augen) shape as a result of being affected by the Allaqi Heiani shear zone.

The structural patterns in the present study are interpreted as the result of the fieldwork and analysis of the ASTER images. The structural features comprise the ductile (foliation, folding, lineation and boudinage structures) and brittle features (faults and dykes) affected by the AllaqiHeiani shear zone.

The folding structure in the studied district is well exhibited by the metamorphic rock units, especially the metasediments where they are principally expressed by major and minor folds. Folds of the metasediments in the Wadi Tilal Al -Qulieb area are best exemplified by the folding formed essentially by highly schistose metasediments. It is a result of compression affect folding (anticline and syncline) with a chevron structure. The most important of these folds is outlined in the central part; extending from Wadi Heisurbah passing in a northwestern direction across Wadi Umm Arka to the tributaries of Wadi Ashira for a distance of about $18 \mathrm{~km}$.

The axial plane of anticlinal fold-oriented NW-SE and is plunging with a moderate angle to SE. The fold shows a gentle plication in the ENE direction; onsetting of a later deformation. The folding of this deformation exhibits a wavelength of about $10 \mathrm{~km}$ and a steep angle in the same direction. The minor folds are extremely developed along the main foliation and within the limbs and hinges of major folds. Their axial traces vary in distances from $2.2 \mathrm{~km}$ to some of the millimeters. 
The major strike-slip fault is wadi Um Arka sinistral fault that run subparallel to Um Ashira major fault that led to lateral movement of metasediment (pale green) and the marble bands (pink color) horizontal displacements of about $100 \mathrm{~m}$ to $747 \mathrm{~m}$. Restraining bend structure (sigmoidal=augen shape) formed result of a sinistral fault.

The final map according to field study and remote sensing methodology showing the lithological composition and structure localities. Comparing the obtained geological map from the present study with the previously published map reveals the accuracy of the obtained map and the good discrimination of the lithological with editing in the present map.

\section{References}

Abdeen, M. M., A.A. Abdelghaffar, 2011. Syn- and post-accretionary structures in the Neoproterozoic central Allaqi-Heiani suture zone, southeastern Egypt. Precambrian Research, 185: 95-108.

Abdeen, M.M., A.K. Thurmond, M.G. Abdelsalam, and R.J. Stern, 2001. Application of ASTER band-ratio images for geological mapping in arid regions; the Neoproterozoic Allaqi Suture, Egypt, Geological Society of America Annual Meeting, November 5-8, 2001, Boston, Massachusetts.

Abdel Rahman, E., N. Qaaud, A. Emam, and N.M. Abdou' 2013. Plutonites of Wadi Um Arka, Allaqi region, South Eastern Desert, Egypt: remote sensing and geochemical aspects. Journal of Biology and Earth Sciences, 3(2):E18-E38.

Abdelsalam, M.G., and R.J. Stern, 1996. Sutures and shear zones in the Arabian-Nubian shield. Journal of African Earth Sciences, 23: 289-310.

Abdelsalam, M.G., M.M. Abdeen, H.M. Dowidar, R.J. Stern, and A.A. Abdelghaffar, 2003. Structural evolution of the Neoproterozoic western Allaqi-Heiani suture zone, Southern Egypt. Precambrian Res., 124: 87-104.

Abdul Aziz, A.M., 1999. Geology and Geotectonics of the area around Wadi Umm Araka,Allaqi district,South Eastern Desert, Egypt. Master Degree, Zagazig University, Benha branch.

Abu El-Leil, I., N.M.A. Soliman, M.H. Bekiet, and M.S. Elhebiry, 2019. Enhancing multispectral remote sensing data interpretation for historical gold mines in Egypt: a case study from Madari gold mine. Arabian Journal of Geosciences 12(1).DOI:10.1007/s12517-018-4081-6.

Abrams, M.J., D. Brown, L. Lepley, and R. Sadowski, 1983. Remote sensing for porphyry copper deposits in southern Arizona. Economic Geology, 78(4): 591-604.

Ahmed A.A., 2002. Geological, petrological, structural and geochemical studies of the Pan- African rocks at Wadi El Qulieb area South Eastern Desert-Egypt, PhD. Thesis, Faculty of Science, AlAzhar University, 205.

Akaad, M.K. and A.M. Noweir, 1980. Geology and Lithostratigraphy of the Arabian Desert orogenic belt of Egypt between Lat. $25^{\circ} 35^{\prime}$ and $26^{\circ} 30^{\prime}$ N. Precambrian Research, 6(1), A6. DOI: 10.1016/0301-9268(78)90063-3.

Amer, R., T. Kusky, and A. El-Mezayen, 2012. Remote sensing detection of gold related alteration zones of Um Rus Area, Central Eastern Desert of Egypt. Adv Space Res 49: 121-134.

Geological Survey of Egypt, 1996. Geologic Map of Jabjabah Quadrangle Egypt at a scale of $1: 250.000$.

El-Afandy, A.H., A.M. EL Mezayen, E.M. Abdel Rahman, F.A. Ammar, and A.A. Ahmed, 2007. Geological and Geochemistry Studies of the Pan-African rocks at Wadi El- Qulieb area, South area, Southeastern Desert, Egypt. Sci. J. Fac. Sci. Minufia Univ., XXI: 159-19.

El-Desoky, H.M., A.A. Afifi, M.A. Heikal, and A.M. Abdel-Rahman, 2019. The use of Egyptian gabbroic rocks from wadi allaqi district in cement clinker production. Annals Geol. Surv. Egypt. V. XXXIV: 941-165.

El Ghrabawy, O., N. Soliman, and A. Tarshan, 2019. Remote sensing signature analysis of ASTER imagery for geological mapping of Gasus area, central eastern desert, Egypt. Arabian Journal of Geosciences. 
El-Nisr, S.A., A.M. Moghazi, and M.M. El Sayed, 1996. Geochemical variations and tectonic significant of the mafic rocks on the Allaqi-Haimur-qulieb area, South Eastern Desert, Egypt. Jour. Geol., 40(2): 555-586.

El-Ramly, M.F., 1972. A new geological map for the basement rocks in the Eastern and Southwestern Deserts of Egypt, Scale 1: 100.000, Annals of the Geological Survey of Egypt, Vol. II, pp.1-12.

El-Shazly, E.M., 1964. On the classification of the Precambrian and other rocks of magmatic affiliation in Egyptian procedure. $22^{\text {nd }}$ Inter Geol Congr New Delhi, India, 10: 88-101.

El-Shimi, K.A., 1992. Application of Remote Sensing techniques to regional geology and tectonic in Wadi Allaqi area southwest, Eastern Desert of Egypt. MSc. Thesis International Institute Aerospace and Earth Sciences (ITC) Enschade the Netherlands.

El-Shimi, K.A., 1996. Geology, structure and Exploration of Gold Mineralization in Wadi Allaqi area (SW, Eastern Desert, Egypt). Ph. D. Thesis (unpub.), Ain Shams Univ., 326.

Environment for Visualizing Images (ENVI), L3 Harris Geospatial documentation center, http://www.exelisvis.com.

Fossen, H., 2010. Structural Geology - Cambridge Books Online - Cambridge

Gao, J., 2008. Digital analysis of remotely sensed imagery. McGraw-Hill Professional.

Greiling, R.O., M.M. Abdeen, A.A. Dardir, H. El Akhal, M.F. El Ramly, G.M. Kamal El Din, A.F. Osman, A.A. Rashwan, A.H.N. Rice, and M.F. Sadek, 1994. A structural synthesis of the Proterozoic Arabian - Nubian Shield in Egypt. Geol. Rundsch, 83: 484-501.

Hamimi, Z., and Y. El-Kazzaz, 2000. Fold geometry and folding mechanism in Um Krush Klippe, south Eastern Desert, Egypt. GAW Cairo Univ, 5: 605-618.

Kusky, T.M. and T.M. Ramadan, 2002. Structural controls on Neoproterozoic mineralization in the South Eastern Desert, Egypt: an integrated field, Landsat TM, and SIR-C/X SAR approach, Journal of African Earth Sciences, 35(1):107-121.

Noweir, A.M., A.A. Rashwan, A.M. Abu El Ela, and M.A.A. El Hashash, 2000. Petrology, petrochemistry and crustal evolution of the Precambrian rocks, Wadi Um Ashira, South Eastern Desert, Egypt. Annals of the Geological Survey of Egypt, 18(3): 961-981.

https://eurekamag.com/research/019/715/019715115.php

Noweir, A.M., M.A. El-Amawy, A.A. Rashwan, and A.M. Abdel-Aziz, 1996. Geology and structural evolution of the Pan-African basement rocks around Wadi Umm Araka, Northeast Wadi Allaqi, South Eastern Desert, Egypt. Egyptian Jour. of Geol., 40(2): 477-512.

Radwan, A.M., 2013. Geological studied on the evolution of some Pan-African Domains North Wadi Allaqi, SED, Egypt. MSc. Aswan University.

Sabins, F.F., 1997. Remote sensing strategies for mineral exploration. In: Rencz AE (ed) Remote Sensing for the Earth Sciences. John Wiley \& Sons, Inc., New York, 375-447.

Saleh, G.M., and A.A. Abd El Wahed, 2000. Pan African granitoid rocks from Arabian shield, SE Aswan, Egypt: Geology, geochemistry and radioactivity. The Fifth International Conference on the Geology of the Arab World, Feb, Cairo Univ.

Salem, S.M., and N.M. Soliman, 2015. Exploration of gold at the east end of Wadi Allaqi, South Eastern Desert, Egypt, using remote sensing techniques. Arabian Journal of Geosciences, 8(11): 9271-9282.

Shalaby, B.N., H.M. El-Desoky, M.A. Heikal, and A.M. Abdel-Rahman, 2019. Petrology and PhysicoMechanical Properties of Wadi Allaqi Ornamental Stones, Southern Eastern Desert, Egypt. Egyptian Journal of Geology, 63: 341-353.

Taylor, W.E.G., Y.A. El Kazzaz, and A.A. Rashwan, 1993. An outline of the tectonic framework for the Pan-African orogeny in the vicinity of Wadi Urn Relan area, south Eastern Desert, Egypt. In lliorweibe, U. \& Schandelmeier, H. (eds) Geoscientific Research in northeast Africa, 31 - 34. University Press. doi:10.1017/cbo9780511777806. ISBN 9780511777806.

Vincent, K.R., 1997. Fundamentals of Geological and Environmental Remote Sensing. Prentice Hall, Upper Saddle River, New Jersey.

Zoheir, B., A. Emam, M. Abd El-Wahed, and N. Soliman, 2019. Gold endowment in the evolution of the Allaqi-Heiani suture, Egypt: A synthesis of geological, structural, and space-borne imagery data. Ore Geology Reviews, 110 (22): 102938.

https://doi.org/10.1016/j.oregeorev.2019.102938. 